\title{
ORAl1 Gene
}

National Cancer Institute

\section{Source}

National Cancer Institute. ORA/1 Gene. NCI Thesaurus. Code C88517.

This gene plays a role in calcium transport and T-cell-mediated immune responses. 